\title{
Polyaromatic hydrocarbons accentuate malignant phenotype of the PC3 prostate cancer cell line
}

\author{
Mariana O Freitas ${ }^{1,2,3^{*}}$, José Oliveira' ${ }^{1}$, Ana M Fernandes ${ }^{1}$, Maria I Coutinho' ${ }^{1}$, Vera Alves ${ }^{4}$, Anabela Mota-Pinto ${ }^{1,2}$, \\ Ana B Sarmento-Ribeiro $2,3,5$ \\ From 16th International Charles Heidelberger Symposium on Cancer Research \\ Coimbra, Portugal. 26-28 September 2010
}

Prostate cancer risk factors are mainly associated to an increase of oxidative stress (OS) related with ageing, genetics, recurrent inflammation, life style or carcinogens exposure as polycyclic aromatic hydrocarbons (PAHs). These last one are ubiquitous environmental contaminants resultant from the incomplete combustion of carbon-containing fuels such as tobacco, wood, diesel, or charbroiled [1,2].

Although numerous studies have related polycyclic aromatic hydrocarbons (PAHs) to tumour formation, few investigations have addressed PAHs effects on prostate cancer progression. Here we investigated the effect of four PAHs namely, pyrene, benzo(a)pyrene, chrysene and benzo(k)fluoranthene on cell growth and cell cycle progression, viability, mitochondria membrane potential, reactive oxygen species (ROS) production, vascular endothelial growth factor (VEGF) and hypoxia inducible factor (HIF) expression in the prostate cancer cell line, $\mathrm{PC} 3$, derived from bone metastasis.

Our data demonstrated that PAHs can stimulate cell growth, in line with an increase of the S-phase of the cell cycle, and mitochondria membrane potential. These results are also concomitant with an increase in VEGF and HIF expression and ROS levels, usually implicated in cancer progression, suggesting that PAHs can contribute to a more aggressive prostate cancer phenotype.

\footnotetext{
Author details

'General Pathology Institute, Faculty of Medicine, University of Coimbra, Coimbra, Portugal. ${ }^{2}$ Center for Investigation in Environment, Genetics and Oncobiology (CIMAGO), Coimbra, Portugal. ${ }^{3}$ Center of Neurosciences and Cell Biology (CNC), University of Coimbra, Coimbra, Portugal. ${ }^{4}$ Immunology Institute, Faculty of Medicine, University of Coimbra, Coimbra, Portugal.
}

\footnotetext{
* Correspondence: freitas.mariana@gmail.com

'General Pathology Institute, Faculty of Medicine, University of Coimbra, Coimbra, Portugal

Full list of author information is available at the end of the article
}

${ }^{5}$ Biochemistry Institute, Faculty of Medicine, University of Coimbra, Coimbra, Portugal.

Published: 24 September 2010

\section{References}

1. Minelli A, Bellezza I, Conte C, Culig Z: Oxidative stress-related aging: a role for prostate cancer? Biochim Biophys Acta 2009, 1795:83-91.

2. Nelson WG, DeMarzo AM, Isaacs WB: Mechanisms of disease - prostate cancer. N Engl J Med 2003, 349:366-381.

doi:10.1056/NEJMra021562

Cite this article as: Freitas et al:: Polyaromatic hydrocarbons accentuate malignant phenotype of the $\mathrm{PC} 3$ prostate cancer cell line. BMC

Proceedings 2010 4(Suppl 2):P26.
Submit your next manuscript to BioMed Central and take full advantage of:

- Convenient online submission

- Thorough peer review

- No space constraints or color figure charges

- Immediate publication on acceptance

- Inclusion in PubMed, CAS, Scopus and Google Scholar

- Research which is freely available for redistribution

Submit your manuscript at www.biomedcentral.com/submit
C Biomed Central 